DOE/me/ 23.72-TI4

QUARTERLY TECHNICAL PROGRESS REPORT 4

JULY - SEPTEMBER, 1987

\title{
ENHANCED LURABILITY AND REACTIVITY FOR \\ ZINC FERRITE DESULFURIZATION SORBENT
}

By

Mahesh C. Jha

Mark H. Berggren

A.MAX Research \& Development Center 5950 McIntyre Street

Golden, Colorado 80403-7499

\section{Prepared for}

U.S. Department of Energy

Morgantown Energy Technology Center

P. O. Box 880

3610 Collins Ferry Road

Morgantown, West Virginia 26507-0880

DOE Contract No. DE-AC21-86 MC23172

AMAX Project No. 80270

October 27,1987

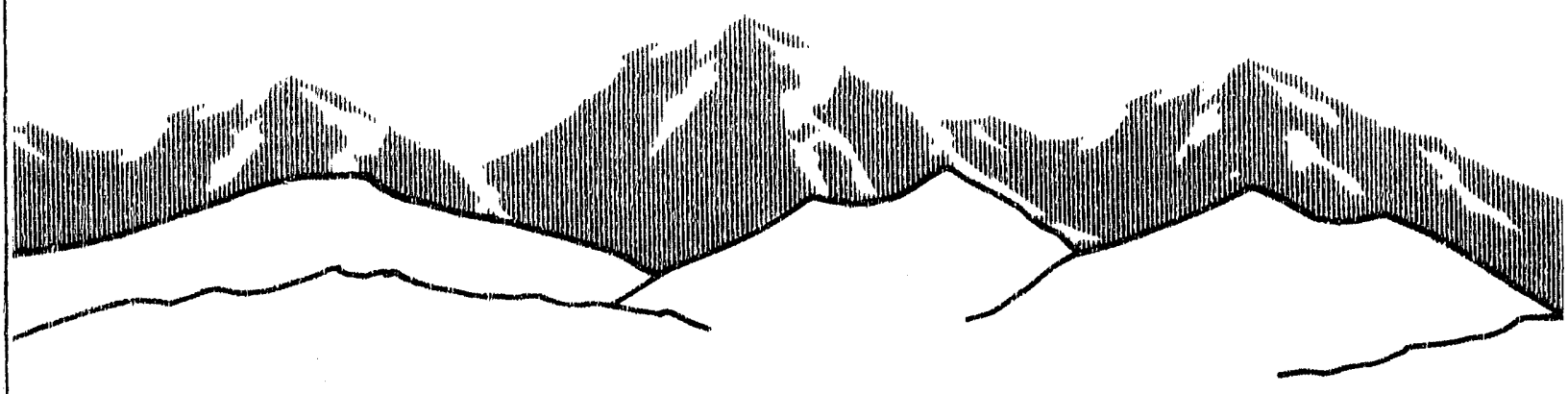

AMAX Research \& Development Center

5950 Mclntyre Street - Golden, Colorado 80403-7499

98 amnax

i. .

$1,4+\cdots$ 


\section{LEGAL NOTICE}

THIS REPORT WAS PREPARED BY AMAX RESEARCH \& DEVELOPMENT CENTER, AS AN ACCOUNT OF WORK SPONSORED BY MORGANTOWN ENERGY TECHNOLOGY CENTER. NEITHER AMAX RESEARCH \& DEVELOPMENT CENTER NOR ANY PERSON ACTING ON ITS BEHALF:

(A) MAKES ANY WARRANTY, EXPRESSED OR IMPLIED, WITH RESPECT TO THE USE OF ANY

INFORMATION, APPARATUS, METHOD, OR PROCESS DISCLOSED IN THIS REPORT OR THAT SUCH USE MAY NOT INERINGE PRIVATELY OWNED RIGHTS ; OR

(B) ASSUMES ANY LIABILITIES WITH RESPECT TO THE USE OF, OR FOR THE DAMAGES RESULTING FROM THE USE OF, ANY INEORMATION, APPARATUS, METHOD, OR PROCESS DISCLOSED IN THIS REPORT. 
DOE/MC/23172--T14

DE92 017770

\title{
QUART.ERLY TECHNICAL PROGRESS REPORT 4 JULY - SEPTEMBER, 1987 \\ ENHANCED DURABILITY AND REACTIVITY FOR ZINC FERRITE DESULFURIZ ATION SORBENT
}

\author{
By \\ Mahesh C. Jha \\ Mark H. Berggren \\ AMAX Research \& Development Center \\ 5950 McIntyre Street \\ Golden, Colorado 80403-7499 \\ Prepared for \\ U.S. Department of Energy \\ Morgantown Energy Technology Center \\ P. O. Box 880 \\ 3610 Collins Ferry Road \\ Morgantown, West Virginia 26507-0880 \\ DOE Contract No. DE-AC21-86 MC23172 \\ AMAX Project No. 80270
}

October 27,1987

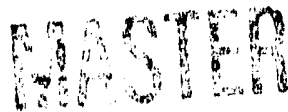




\section{TABLE OF CONTENTS}

Page

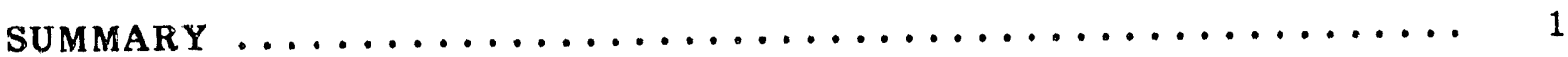

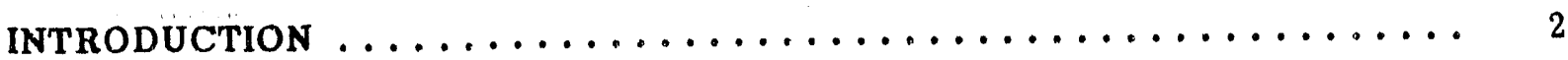

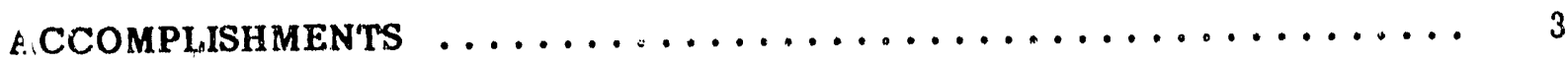

TASK 1. EXPERIMENTAL TEST PLAN $\ldots \ldots \ldots \ldots \ldots \ldots \ldots \ldots \ldots \ldots \ldots \ldots \ldots \ldots$

TASK 2. SORBENT PREPARATION AND CHARACTERIZATION ...... 3

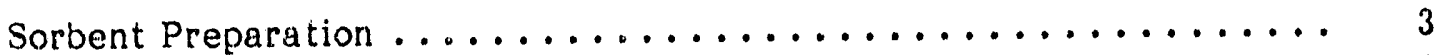

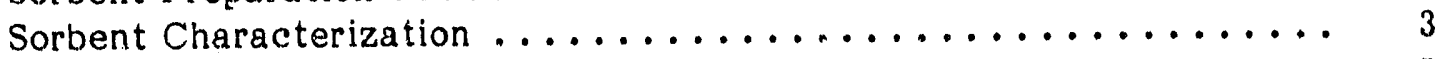

TASK 3 , BENCH-SCALE TESTING ................... 5

Bench-Scale Test Results . . . . . . . . . . . . . . . . . 5

Alternate Regeneration Procedure Testing $\ldots \ldots \ldots \ldots \ldots \ldots \ldots \ldots$

Single Particle Kinetic Studies at LSU .................. 11

TASK 4. BENCH-SCALE TEST ANALYSIS $\ldots \ldots \ldots \ldots \ldots \ldots \ldots \ldots$

REFERENCES $\ldots \ldots \ldots \ldots \ldots \ldots \ldots \ldots \ldots \ldots \ldots \ldots \ldots \ldots \ldots \ldots \ldots$

APPENDIX A

\section{APPENDIX B}

MINERALOGICAL ANALYSIS OF ZINC FERRITE SORBENT

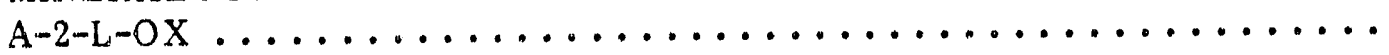




\section{LIST OF TABLES}

Page

Table 1. Preparation, Characterization, and Testing of

Zinc Ferrite Sorbents ..................... 4

Table 2. Sorbents Used for Bench-Scale Testing $\ldots \ldots \ldots \ldots \ldots \ldots$

Table 3. Calculated Percent Sulfur Loading at $200 \mathrm{ppm}$ $\mathrm{H}_{2} \mathrm{~S}$ Breakthrough for 10 Cycles of Bench-Scale

Testing Using Sorbents Formulated at AMAX R\&D $\ldots \ldots \ldots \ldots$

Table 4. Summary of Sulfur Dioxide Regeneration Test

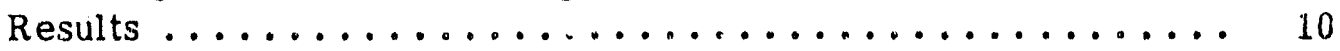

Table 5. Summary of Base Case Sorbent Characteristics . . . . . . . . 13

Table $6 . \quad$ Summary of Sorbent P11A Characteristics $\ldots \ldots \ldots \ldots \ldots$

\section{LIST OF FIGURES}

Figure 1. Hydrogen sulfide gas concentration in exit gas

during sulfidation to saturation. ............... 7

Figure 2. Temperature profiles during sulfidation to

saturation. ........................... 7

Figure 3. Sulfur dioxide and oxygen gas concentrations

during first-stage regeneration. ................ 8

Figure 4. Temperature profiles during first-stage

regeneration. $\ldots \ldots \ldots \ldots \ldots \ldots \ldots \ldots \ldots \ldots \ldots \ldots$

Figure 5. Sulfur dioxide and oxygen gas concentrations

during second-stage regeneration. ................ 9

Figure 6. Temperature profiles during second-stage

regeneration. .......................... 9

Figure 7. Effect of regeneration temperature on sulfidation

performance using sorbent E7. .................. 12 


\section{SUMMARY}

AMAX Research \& Development Center (AMAX R\&D) has been investigating methods for improving the reactivity and durability of the zinc ferrite desulfurization sorbent. Zinc ferrite sorbents are intended for use in desulfurization of hot coal gas in integrated gasification combined cycle (IGCC) or molten carbonate fuel cell (MCFC) applications. The reactivity of the sorbent may be defined as its sulfur sorption capacity at the breakthrough point in a bench-scale fixed-bed reactor. The durability may be defined as the ability of the sorbent to maintain its reactivity and other important physical characteristics such as size, strength, and specific surface area during 10 cycles of sulfidation and regeneration. Two base case sorbents, spherical pellets and cylinarical extrudes used in related METC sponsored projects, are being used to provide a basis for the comparison of physical characteristics and chemical reactivity.

During the fourth quarter of the project (July - September, 1987), cyclic benchscale testing of the base case sorbents was completed and the sulfidized sorbents were characterized. New cylindrical extrude and spherical pellet sorbent formulations were prepared. Bench-scale testing was performed on selected sorbents. Additional single particle kinetic studies were carried out at Louisiana State University.

A special two-stage regeneration test procedure was also investigated during the quarter. A synthetic recycled regeneration gas containing sulfur dioxide, nitrogen, and oxygen was used to simulate the potential commercial process which would allow a sulfur-dioxide-rich gas stream to be generated from the sulfidized sorbent without the use of steam. The first stage of regeneration is performed at relatively low temperature $\left(454^{\circ} \mathrm{C}\right)$ to form sulfates from the sulfidized sorbent. The second stage of regeneration is performed at higher temperature $\left(760^{\circ} \mathrm{C}\right)$ to decompose the sulfates to zinc ferrite and sulfur dioxide. 


\section{INTRODUCTION}

The U.S. Department of Energy (DOE), through the Morgantown Energy Technology Center (METC), has been investigating a number of advanced systems for producing electric power frcm large coal reserves available in the United States. The integrated gasification combined cycle (IGCC) concept has been identified as one of the most promising technologies for coal utilization. The goal of hot coal gas cleanup programs at METC is to develop contaminant control technologies that operate under conditions compatible with those of the gasifier and power generator (gas turbine or molten carbonate fuel cell).

Sulfur control at high temperature and pressure forms a major portion of the hot gas cleanup program at METC. Previous research has established that hightemperature desulfurization can be accomplished using solid zinc ferrite sorbents to remove sulfur species from the coal gas to the 10 ppmv level or less, and the sorbent can be regenerated with air for reuse. The zinc ferrite sorbents experience chemical, physical, and thermal changes during sulfidation and regeneration. Deterioration of sorbent performance and physical characteristics is strongly influenced by the chemical composition of the sorbent and the method of preparation.

The objective of the present contract is to systernatically investigate methods for enhancing the physical durability and chemical reactivity of the zinc ferrite desulfurization sorbent.

The program is divided into the following five tasks:

Task 1. Experimental Test Plan

Task 2. Sorbent Preparation and Characterization

Task 3. Bench-Scale Testing

Task 4. Bench-Scale Test Analysis

Task 5. Topical Report sections.

Accomplishments for each of the major tasks are summarized in the following 


\section{ACCOMPLISHMENTS}

\section{TASK 1. EXPERIMENTAL TEST PLAN}

Some modification to the test plan was made to allow for the testing of an alternate regeneration scheme. The alternate regeneration scheme is to be performed using two different superficial gas velocities ( 2 and 3 feet per second). As a result of this contract modification, the number of sorbents to be tested in the bench-scale apparatus will be reduced to 13 during the base contract, which is now scheduled to be completed by October 1988.

\section{TASK 2. SORBENT PREPARATION AND CHARACTERIZATION}

\section{Sorbent Preparation}

Additional sorbents were prepared from the statistical screening design matrix. Formulations of cylindrical extrudes containing 10 percent bentonite could not be prepared in sufficient quantity for testing due to significant sticking and plugging in the extrusion chamber. Table 1 summarizes the status of sorbent preparation, characterization, and bench-scale testing.

\section{Sorbent Characterization}

Sorbents which were prepared for eyclic bench-scale testing were characterized for physical properties. Table 2 summarizes the formulations, induration conditions, and physical properties of the three sorbents which have been or are currently being tested. Characterizations are being performed on recently prepared extrude and pellet sorbents.

Trble 2. Sorbents Used for Bench-Scale Testing

\begin{tabular}{|c|c|c|c|}
\hline Sorbent Formulation & $\underline{\mathrm{P} 11 \mathrm{~A}}$ & $\underline{E 13 A}$ & $\underline{P 6 A}$ \\
\hline Preparation Run Number & 3 & 7 & 2 \\
\hline Sorbent Shape & Pellet & Extrude & Pellet \\
\hline Iron Oxide Grade & Catalyst & Catalyst & Pigment \\
\hline $\mathrm{ZnO} / \mathrm{Fe}_{2} \mathrm{O}_{3}$ Molar Ratio & 1.0 & 1.0 & 0.8 \\
\hline Bentonite Content, $\%$ & 2 & 2 & 2 \\
\hline Organic Binder Content, $\%$ & 0 & 0.5 & 0 \\
\hline \multicolumn{4}{|l|}{ Induration Conditions } \\
\hline Temperature, ${ }^{\circ} \mathrm{F}$ & 1,900 & 1,700 & 1,900 \\
\hline Time, Hours & 0.25 & 2 & 4 \\
\hline \multicolumn{4}{|l|}{ Physical Properties } \\
\hline$\overline{\text { Bulk Density, kg/1 }}$ & 1.141 & 1.260 & 1.488 \\
\hline Crush Strength, lb & 16.6 & 33.2 & 22.0 \\
\hline Loss on Attrition, $\%$ & 19.5 & 14.6 & 11.0 \\
\hline BET Surface Area, $\mathrm{m}^{2} / \mathrm{g}$ & 2.63 & 4.06 & 1.68 \\
\hline
\end{tabular}




$$
\text { If }
$$

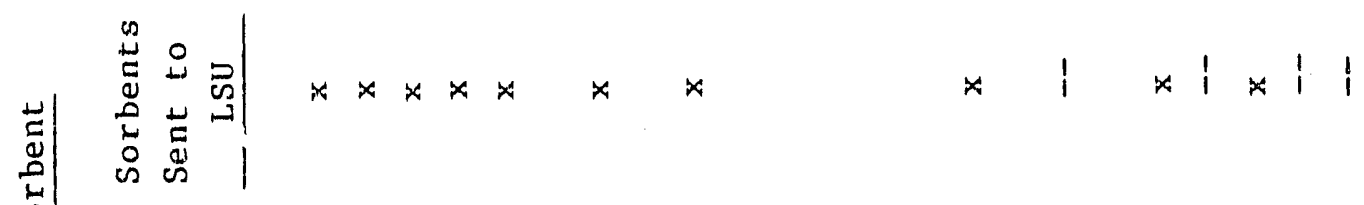

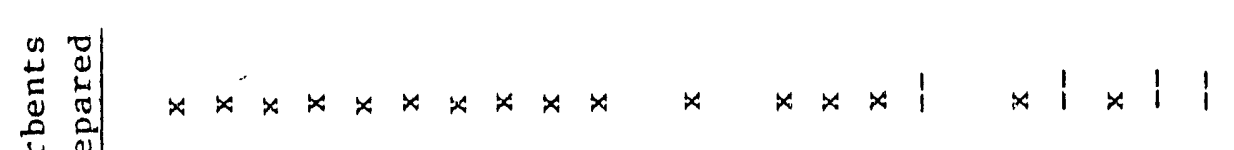
至

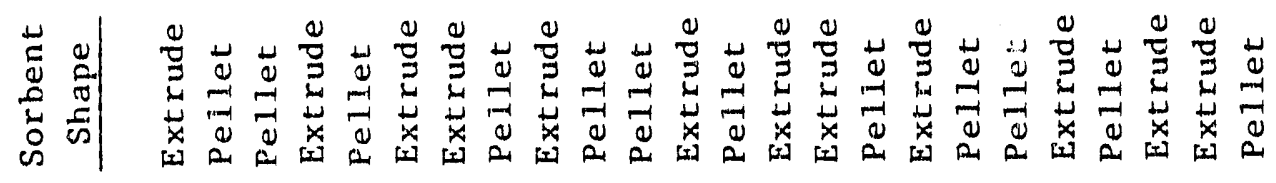

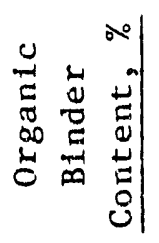

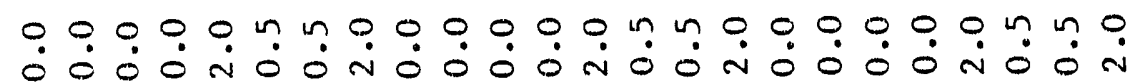

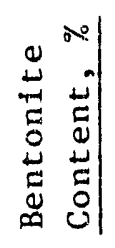

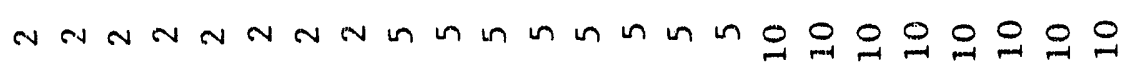

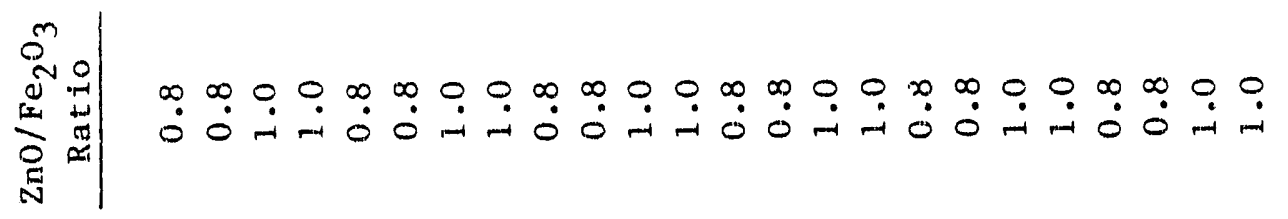

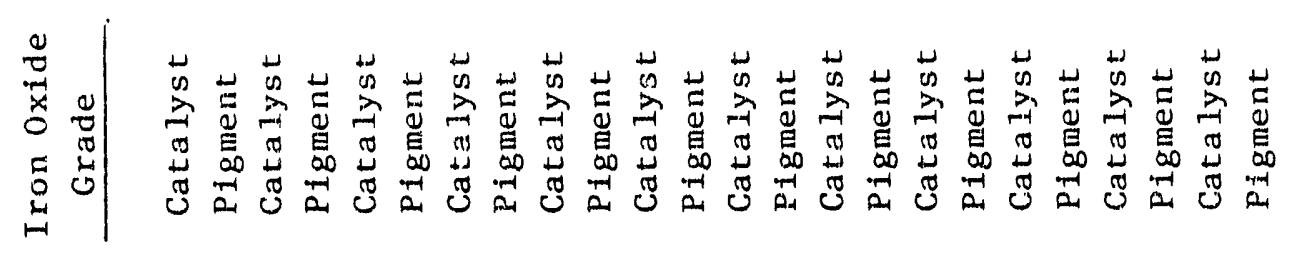

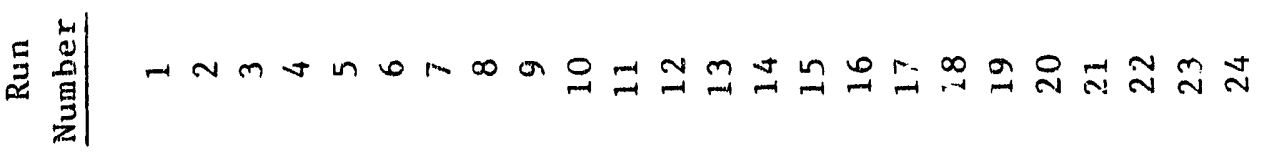


Some mineralogical analyses were performed on selected indurated sorbent samples in order to verify that zinc ferrite (franklinite) had formed from the zinc and iron oxides. Appendix A shows that indurating at $1,500^{\circ} \mathrm{F}$ for 4 hours or at $1,900^{\circ} \mathrm{F}$ for 15 minutes is sufficient to form franklinite. Samples wrich exhitited a hematite phase were those which were formulated using a deficiency of zinc.

\section{TASK 3. BENCH-SCALE TESTING}

\section{Bench-Scale Test Results}

Bench-scale testing was completed using the AMAX 1094-59 base case spherical pellet sorbent and a new sorbent, P11A. Testing of new sorbents E13A and P6A was in progress at the end of the reporting period. A 1.0 percent hydrogen sulfide gas concentration is being used at a test temperature of $550^{\circ} \mathrm{C}$. The base case 1094-59 sorbent exhibited calculated sulfur loadings of only 0.8 to 1.5 percent at hydrogen sulfide breakthrough values of about $200 \mathrm{ppm}$, indicating poor kinetics. Sulfur loadings are based on the calculated weight of sulfur removed from the gas (based on gas flow and analysis) divided by the initial sorbent weight. As reported previousiy, ${ }^{1}$ the sulfidation kinetics are much better at $650^{\circ} \mathrm{C}$ and at lower gas velocities. This was also demonstrated by the fact that the sorbent exhibited a calculated sulfur loading of about 36 percent at $550^{\circ} \mathrm{C}$ at saturation.

Calculated sulfur loadings of 19.5 to 34.2 percent at breakthrough were obtained using the P11A sorbent. Sorbent E13A exhibited calculated sulfur loadings of 15.3 to 20.3 percent at breakthrough during the seven cycles of testing completed by the end of the reporting pariod. Sorbent P6A exhibited sulfur loadings ranging from 16.1 to 8.5 percent at breakthrough during the five cycles of testing which have been completed. P6A exhibited comparatively high crush strength and low loss on attrition for spherical pellet sorbents ( 22 pounds and 11 percent, respectively). Table 3 summarizes the calculated sulfur loadings for each of these sorbents. Sorbent formulation and characteristics are shown in Table 2. Sulfur loading of sorbent P6A, which was prepared using pigment-grade iron oxide, gradually decreased during each cycle of testing. Sorbents which were prepared using catalyst-grade iron oxide have so far not shown similar drops in performance during the cyclic tests.

Table 3. Calculated Percent Sulfur Loading at $200 \mathrm{ppm} \mathrm{H}_{2} \mathrm{~S}$ Breakthrough for 10 Cycles of Bench-Scale Testing Using Sorbents Formulated at AMAX R\&D

\begin{tabular}{|c|c|c|c|c|c|c|c|c|c|c|}
\hline Sorbent & $\begin{array}{c}\text { Cycle } \\
1 \\
\end{array}$ & $\begin{array}{c}\text { Cycle } \\
2 \\
\end{array}$ & $\begin{array}{c}\text { Cycle } \\
3 \\
\end{array}$ & $\begin{array}{c}\text { Cycle } \\
4 \\
\end{array}$ & $\begin{array}{c}\text { Cycle } \\
5 \\
\end{array}$ & $\begin{array}{c}\text { Cycle } \\
6 \\
\end{array}$ & $\begin{array}{c}\text { Cycle } \\
7 \\
\end{array}$ & $\begin{array}{c}\text { Cycle } \\
8 \\
\end{array}$ & $\begin{array}{c}\text { Cycle } \\
9 \\
\end{array}$ & $\begin{array}{c}\text { Cycle } \\
10 \\
\end{array}$ \\
\hline $\begin{array}{l}\text { P11.A } \\
\text { Reactor R) }\end{array}$ & 25.2 & 20.2 & $11.0^{a}$ & 34.2 & 33.0 & 24.8 & 24.0 & 19.5 & 20.3 & 21.0 \\
\hline $\begin{array}{l}\text { E13A } \\
\text { Reactor R) }\end{array}$ & 17.6 & 15.3 & 17.7 & 17.1 & 15.3 & 20.3 & 16.1 & & & \\
\hline $\begin{array}{l}\text { P6A } \\
\text { Reactor L) }\end{array}$ & 16.1 & 14.3 & 13.0 & 10.4 & 8.5 & & & & & \\
\hline
\end{tabular}

a Test cycle was stopped before breakthrough due to reactor plugging. 
As reported previously, ${ }^{1}$ some apparent differences in the base case sorbent reactivity were noted between the two bench-scale reactors. The calculated percent sulfur loadings at $200 \mathrm{ppm} \mathrm{H}_{2} \mathrm{~S}$ breakthrough were consistently som ewhat greater in Reactor $L$ than in Reactor $R$, although the calculated and measured sulfur loading's were very similar at saturation. Further examination of the temperature data showed that while the internal temperatures in both reactors were the same, some apparent difference in the reactor shell temperatures did exist. Both reactors were fabricated from identical 2.5-inch diameter pipe; however, Reactor $R$ is mounted in a 2.5-inch diameter 3-zone furnace, while Reactor $\mathrm{L}$ is mounted in a 3-inch diameter 3 -zone furnace. Reactor $L$ shell temperatures were typically about 50 degrees hotter than the Reactor $\mathrm{R}$ shell temperatures at some locations. These resul ts indicate that a greater temperature profile exists in Reactor $\mathrm{L}$, allowing some sorbent to reach higher temperatures at which improved reactivity is observed. Efforts are underway to obtain a matching furnace for Reactor L.

\section{Alternate Regeneration Procedure Testing}

An alternate regeneration procedure was evaluated using the $\mathrm{UCI} T-2465$ base case sorbent. The objective for a commercial system will be to produce an $\mathrm{SO}_{2}$-rich gas during regeneration without using steam. A test was run using a superficial gas velocity of 3 feet per second for sulfidation to saturation and two stages of regeneration. Sulfidation to saturation was carried out using a 1.0 per cent hydrogen sulfide gas concentration at $593^{\circ} \mathrm{C}\left(1,100^{\circ} \mathrm{F}\right)$. Figures 1 and 2 show the gas composition and temperature profiles, respectively, during the sulfidation step. The temperature profile irregularities in Figure 2 are due primarily to some fluctuations during start-up each day after maintaining a nitrogen gas flow at about $400^{\circ} \mathrm{C}$ overnight. Calculations indicated that the sorbent was fully sulfidized. The first stage of regeneration was performed using an inlet gas temperature of $454^{\circ} \mathrm{C}\left(850^{\circ} \mathrm{F}\right)$. The regeneration gas, containing 12 percent $\mathrm{SO}_{2}, 2$ percent $\mathrm{O}_{2}$, and 86 percent $\mathrm{N}_{2}$, was introduced into the bottom of the 12-inch high reactor column. Figures 3 and 4 show the exit gas composition and temperature profiles during the first stage of regeneration. During the first stage of regeneration, the exit gas was observed to be lower in oxygen concentration and about the same in sulfur dioxide concentration as the inlet gas, indicating that sulfates were probably being formed from the sulfides in the sorbent bed. High levels of sulfur dioxide were noted in the exit gas during the first part of second-stage regeneration. Figures 5 and 6 show the gas composition and temperature profiles, respectively, during the second stage of regeneration. Concentrations were much greater than the measuring capability of the infrared $\mathrm{SO}_{2}$ meter used for monitoring the gas composition. A gas chromatograph was used to obtain later readings, which were about 19 percent $\mathrm{SO}_{2}$ after about 700 minutes of the second stage of regeneration.

Analyses performed on the UCI T-2465 sorbent following the two-step regeneration procedure indicated that sulfates had probably formed during the first stage of regeneration but were largely decomposed during the second stage. Table 4 summarizes the physical and chemical properties before and after testing. Following 


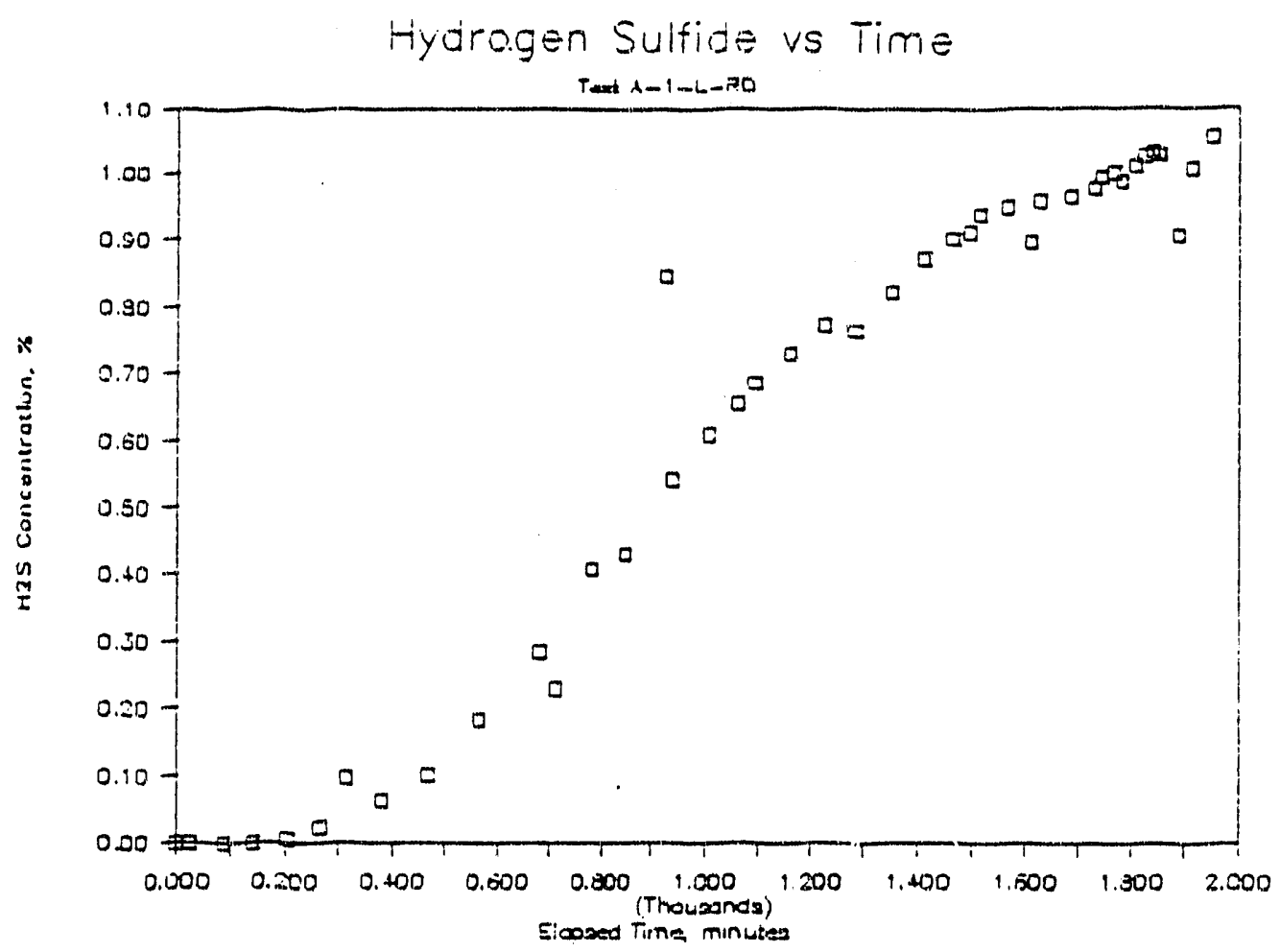

Figure 1. Hydrogen sulfide gas concentration in exit gas during sulfidation to saturation.

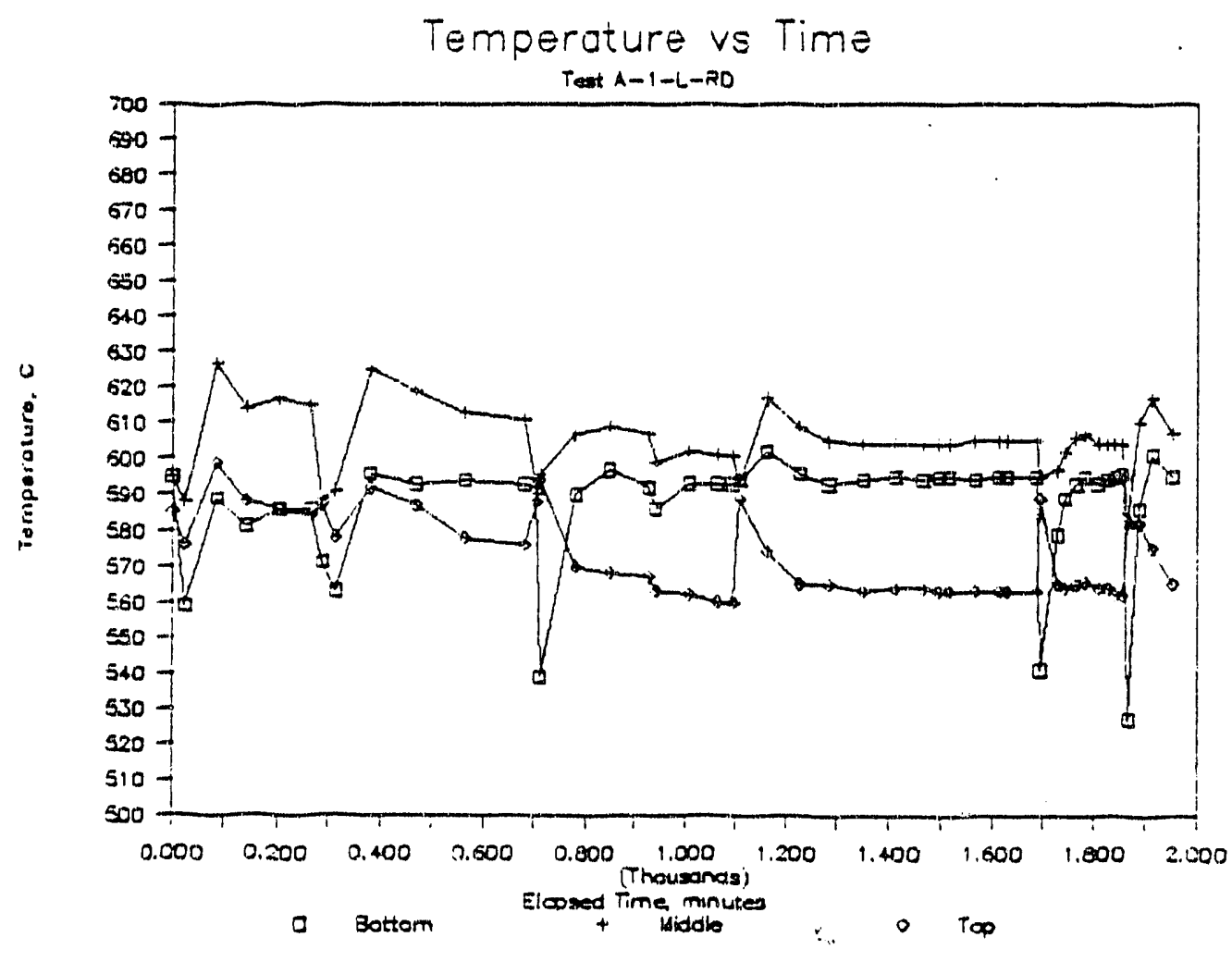

Figure 2. Temperature profiles during sulfidation to saturation. 
Gos Concentrotion vs Time

iat $1-1-i-0 x$

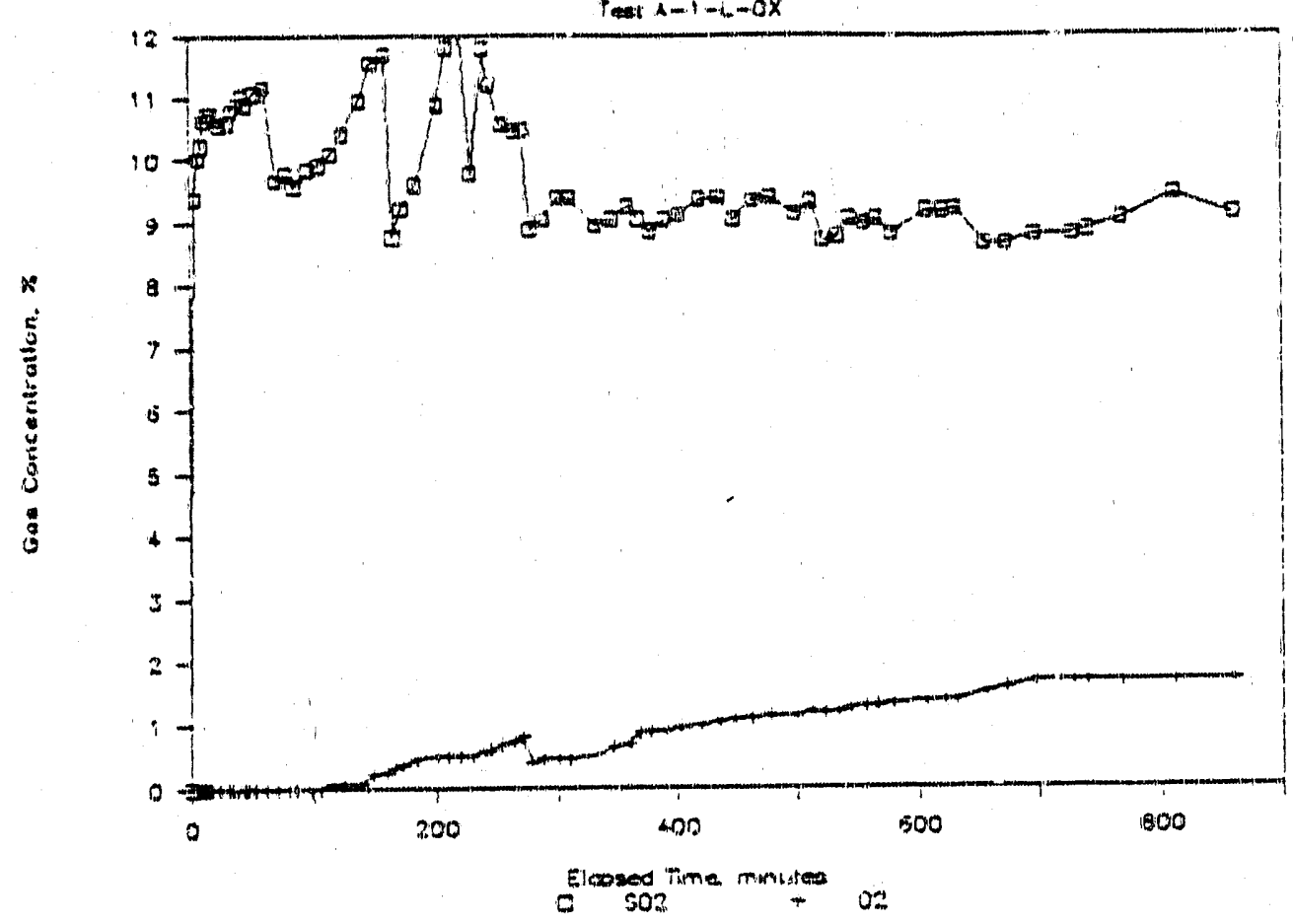

$\mathrm{F}_{i_{i}}$ dre 3. Sulfur dioxide and oxygen gas concentrations during first-stage regeneration.

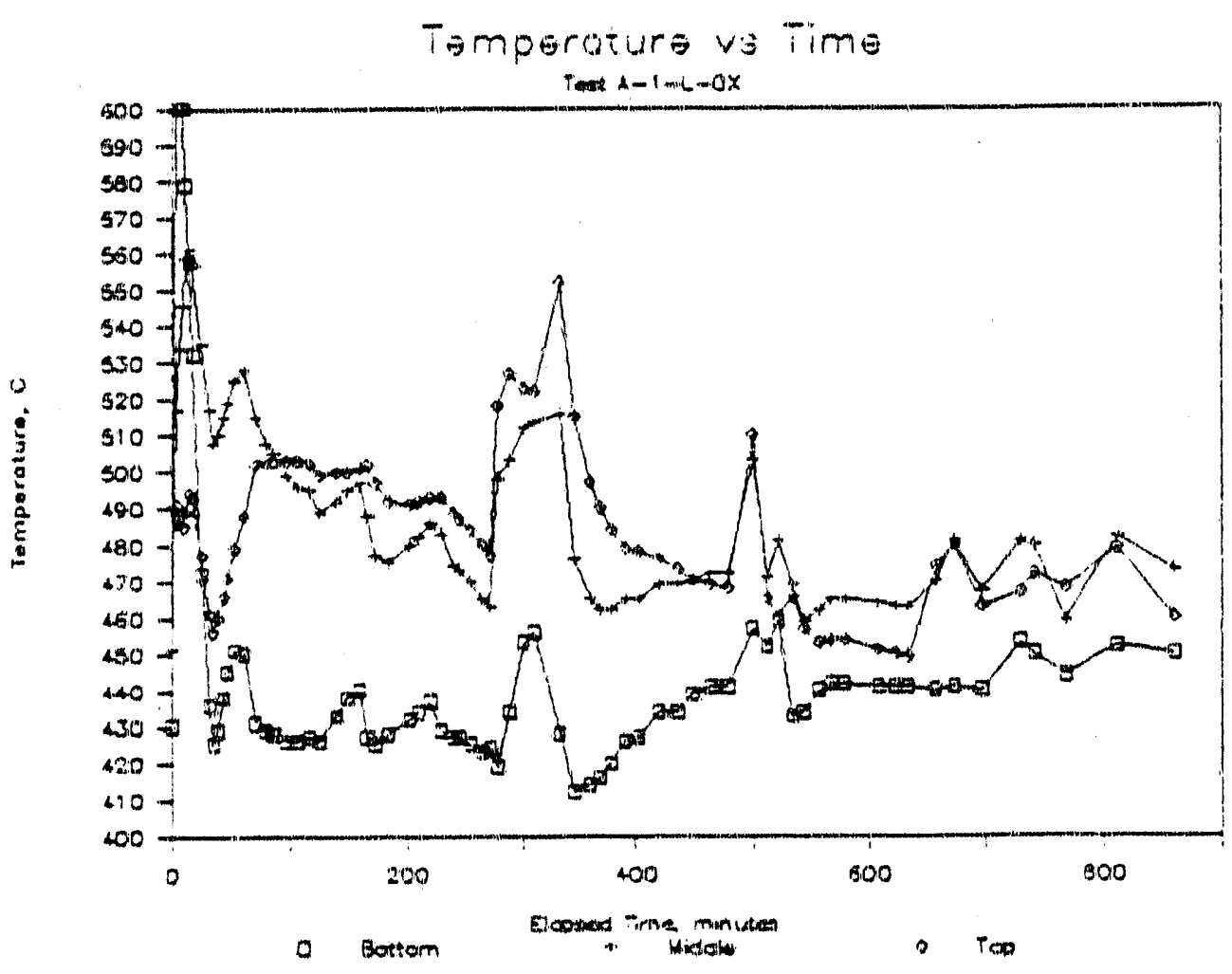

Figure 4. Temperal 'tre profiles during first-stage regeneration. 


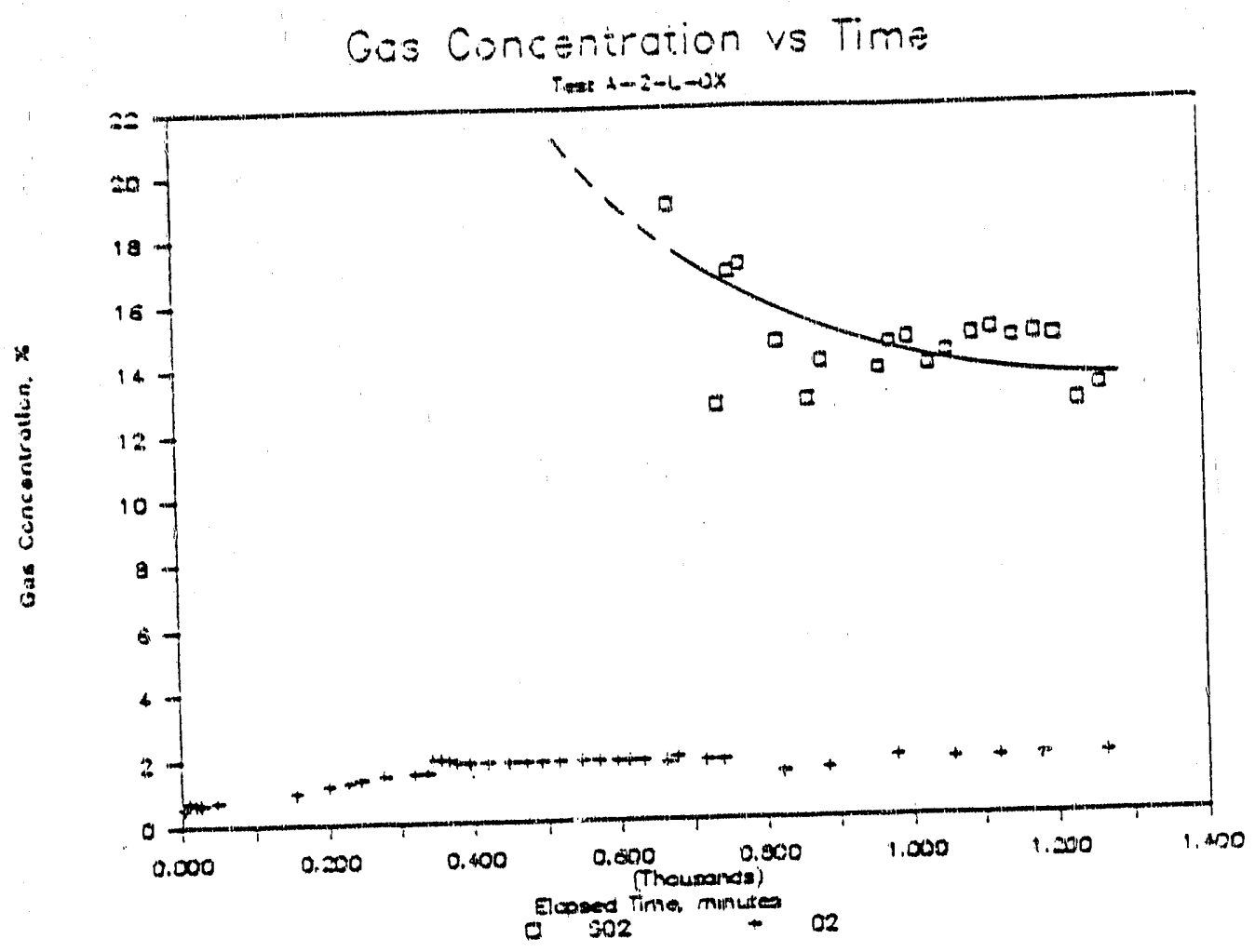

Figure 5. Sulfur dioxide and oxygen gas concentrations during second-stage regeneration.

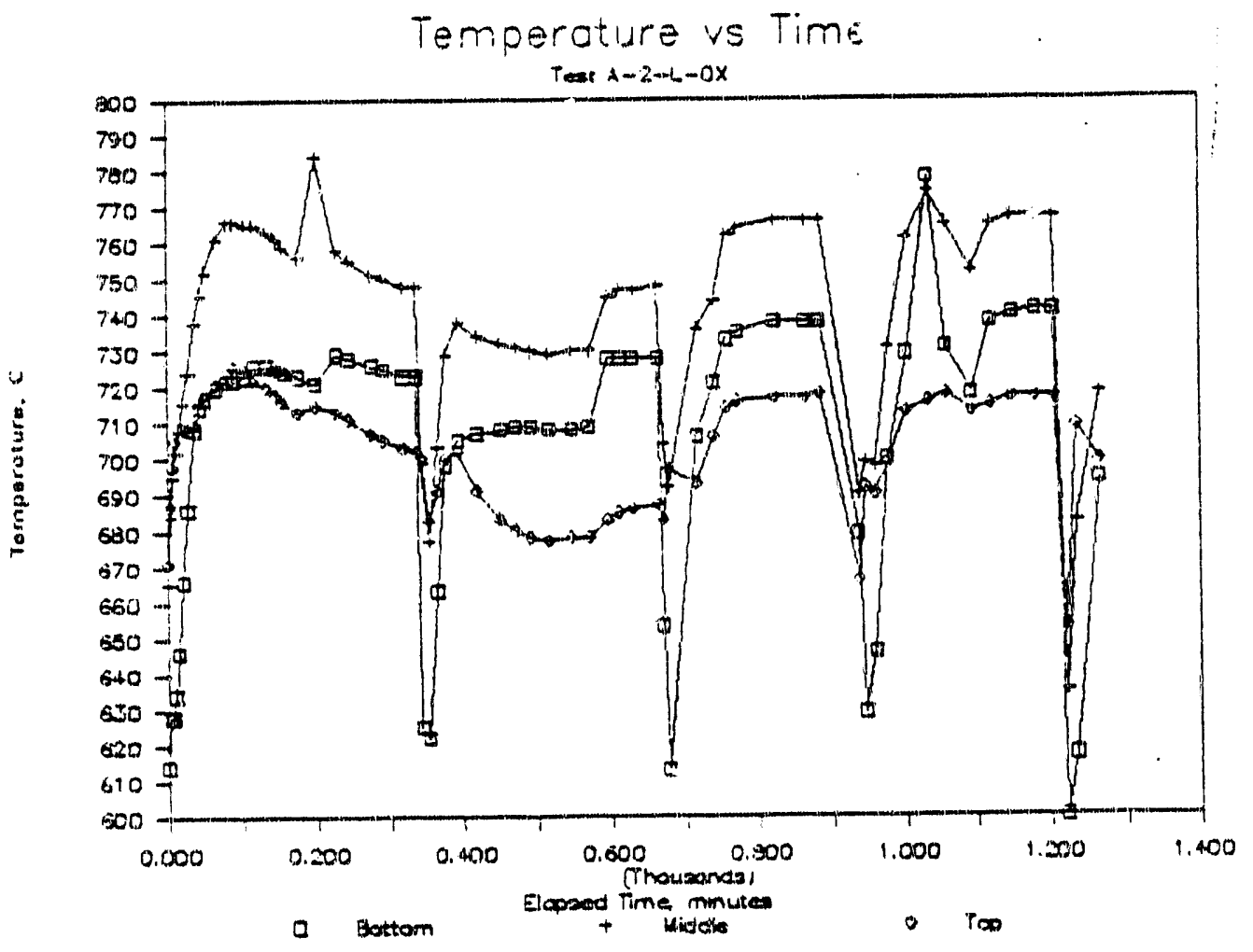

Figure 6. Temperature profiles during second-stage regeneration. 
the second regeneration step, about 1.1 percent total sulfur remained in the sorbent near the bottom the reactor bed. About 2.2 percent total sulfur remained in the surbent near the top of the bed; however, some red-colored sorbent located near the top of the bed was found to contain about 9 percent total sulfur. Chemical analyses showed that essentially all of the sulfur present was in sulfate form. Crush strength of the sorbent decreased following sulfidation and regeneration procedures, while loss on attrition remained nearly the same. Mineralogical analysis showed that a competent rim was present on sorbent taken from throughout the bed. Some sorbent, particularly near the top of the bed, exhibited significant quantities of zinc sulfate (zinkosite) in the interior regions. This zinc sulifate $w$ as of a soft, water-soluble nature. Appendix $B$ details the mineralogy of the sorbent. Results of the test at 3 feet per second are being evaluated prior to conducting a test at 2 feet per second superficial velocity.

Table 4. Summary of Sulfur Dioxide Regeneration Test Results (UCI T -2465 Sorbent, Velocity $=3$ feet per second)

Before After Second-
Testing Stage Regeneration

Physical Analyses Crush Strength, lb Bulk Density, $\mathrm{kg} / \mathrm{l}$ Surface Area, $\mathrm{m}^{2} / \mathrm{g}$ Sorbent Diameter, inch Luss on Atrition, \%

Chemical Analyses

Zinc, $\%$

Feed

Bottom

Top

Top "Red Sorbent"

Iron, \%

Feed

Bottom

Top

Top "Red Sorbent"

Total Sulfur, \%

Feed

Bottom

Top

Top "Red Sorbent"

Sulfate Sulfur, \%

Feed

Bottom

Top

Top "Red Sorbent"
36.0

18.7

3.548

1.324

0.1979

3.078

11.2

0.1966

11.6

26.3

25.1

25.2

20.1

44.9

42.3

42.2

33.2

0.04

1.07

2.23

8.92

1.06

2.26

9.11 
Single Particle Kinetic Studies at LSU

Selected sorbents were subjected to single particle kinetic studies at Louisiana State University. Sorbents examined so far were ranked in order of the first cycle of reactivity. For the cylindrical extrudes, the ranking is as shown below:

$$
\mathrm{T}-2465>\mathrm{E} 2>\mathrm{E} 11>\mathrm{E} 7 \sim \mathrm{E} 24
$$

For the spherical pellet sorbents, the ranking is as shown below:

$$
\mathrm{P} 11 \sim \mathrm{P} 10 \sim \mathrm{P} 5>\mathrm{P} 21>\mathrm{P} 27>1094-59>\mathrm{P} 6
$$

Sorbent formulations and characteristics have been reported previously. ${ }^{1}$ A 2.7 percent hydrogen sulfide gas concentration is used for the single particle kinetic studies in order to complete test runs within a reasonable time period (usually 150 to 250 minutes). The single particle test results do not necessarily agree with cyclic benchscale test results. The reasons for the difference in response could be related to the differences in the temperature profiles in the reactor systems or to the effect of the water-gas shif $t$ reaction.

Additional work at LSU has shown that the sorbents performed better after regeneration at $650^{\circ} \mathrm{C}$ rather than at 700 or $750^{\circ} \mathrm{C}$. Figure 7 illustrates the effect of regeneration temperature on subsequent sulfidation performance.

\section{TASK 4. BENCH-SCALE TEST ANALYSIS}

Chemical analyses and physical properties were determined for the two base case sorbents before and after cyclic testing. Table 5 summarizes the results. The UCI $\mathrm{T}-2465$ sorbent was uniform in iron, zinc, and sulfur distribution as a function of 10.ation in the sorbent column. The AMAX 1094-59 sorbent exhibited sulfur content near the bottom of the bed comparable to the UCI sorbent, but the degree of sulfidation decreased as a function of height in the column. While the sulfur content near the bottom was 30.0 percent, 24.0 percent sulfur existed near the top of the column. Crush strength of the AMAX sorbent increased slightly following 10 cycles of testing, while the UCI sorbent crush strength decreased slightly. An increase in bulk density was observed for each of the sulfidized sorbents. Only a slight decrease in sorbent diameter was noted for the UCI sorbent. Measurements of the AMAX spherical pellet diameters were not meaningful due to the much greater variation compared to the extruded sorbent. However, measurements following the single particle kinetic studies at LSU using the AMAX 1094-59 sorbent indicated an insignificant decrease in sorbent diameter (from 0.2209 to 0.2205 :nch). The surface area of the AMAX sorbent decreased from about 1.0 to $0.9 \mathrm{~m}^{2} / \mathrm{g}$, while the UCI sorbent surface area decreased from 3.3 to $1.5 \mathrm{~m}^{2} / \mathrm{g}$. Loss on attrition of the AMAX base case spherical pellets decreased from about 55 to about 31 percent following cyclic testing. 'The UCI base case sorbent loss on attrition increased from about 11 percent to about 22 percent. A mineralogical report summarizing the x-ray diffraction, optical microscopy, and electron microprobe analyses is pending. 


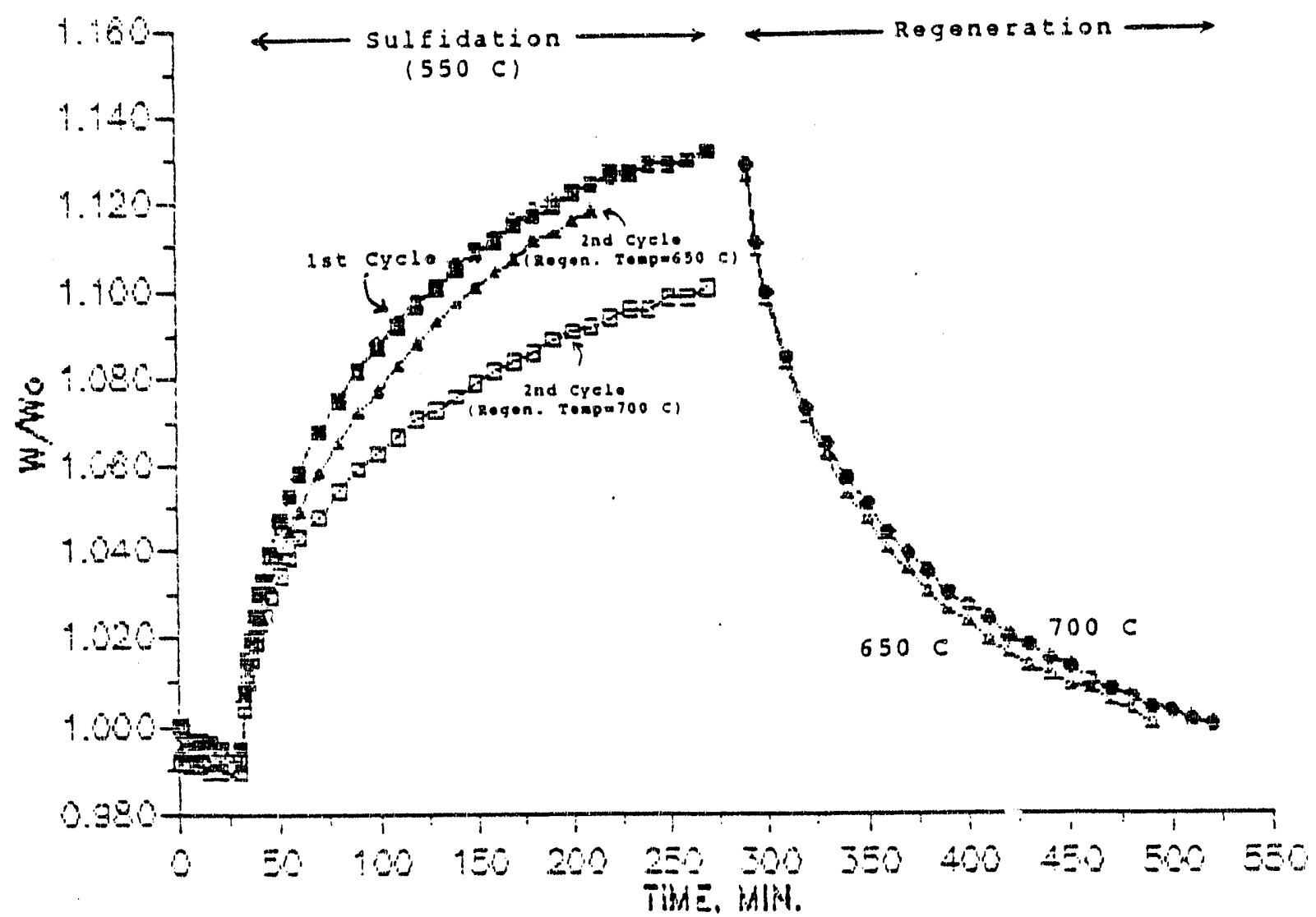

Figure 7. Effect of regeneration temperature on sulfidation performance using sorberit E7. 
Table 5. Summary of Base Case Sorbent Characteristics

\begin{tabular}{cc}
\multicolumn{2}{c}{ UCI T-2465 } \\
$\begin{array}{c}\text { Before Cyclic } \\
\text { Testing }\end{array}$ & After Cyclic \\
Testing
\end{tabular}

Testing

\begin{tabular}{|c|c|}
\hline AMAX & $94-59$ \\
\hline $\begin{array}{l}\text { Before Cyclic } \\
\text { Testing }\end{array}$ & $\begin{array}{c}\text { Aftur Cyclic } \\
\text { Testing }\end{array}$ \\
\hline
\end{tabular}

5.1

1.014

1.01 .

$-$

54.5

\section{Physical Properties}

Crush Strength, lb

Bulk Density, $\mathrm{kg} / \mathrm{l}$

Surface Area, $\mathrm{m}^{2} / \mathrm{g}$

Sorbent Diameter, inch

Loss on Attrition, \%

Chemical Analyses
21.7

21.8

21.6

36.3

35.4

35.7

$\left.\begin{array}{l}24.0 \\ 28.1 \\ 30.0\end{array}\right]$
23.5

23.5

23.5

40.6

40.6

40.6

$\left.\begin{array}{l}30.2 \\ 29.8 \\ 30.3\end{array}\right\} 30.1$

Table 6 summarizes the physical and chemical properties of the sulfidized P11A sorbent, which was subjected to cyclic bench-scale testing and sulfidation to saturation. A mineralogical report is pending. 
Table 6. Summary of Sorbent P11A Characteristics

\begin{tabular}{|c|c|c|}
\hline & $\begin{array}{c}\text { Before Cyclic } \\
\text { Testing }\end{array}$ & $\begin{array}{c}\text { After Cyclic } \\
\text { Testing }\end{array}$ \\
\hline \multicolumn{3}{|l|}{ Physical Properties } \\
\hline Crush Strength, lb & 16.6 & 11.0 \\
\hline Bulk Density, kg/l & 1.141 & 1.279 \\
\hline Surface Area, $\mathrm{m}^{2} / \mathrm{g}$ & 2.63 & 1.27 \\
\hline Loss on Attrition, $\%$ & 19.5 & 31.2 \\
\hline \multicolumn{3}{|l|}{ Chemical Analyses } \\
\hline \multicolumn{3}{|l|}{ Zinc, $\%$} \\
\hline Top & & 22.5 \\
\hline Middle & & 22.6 \\
\hline Bottom & & 22.5 \\
\hline \multicolumn{3}{|l|}{ Iron, $\%$} \\
\hline Top & & 40.6 \\
\hline Middle & & 41.3 \\
\hline Bottom & & 40.9 \\
\hline \multicolumn{3}{|l|}{ Sulfur, $\%$} \\
\hline Top & & 31.5 \\
\hline Middle & & 27.1 \\
\hline Bottom & & 28.8 \\
\hline
\end{tabular}

\section{REFERENCES}

1. Jha, M. C., Baltich, L. K., and Berggren, M. H., "Enhanced Durability and Reactivity for Zinc Ferrite Desulfurization Sorbent", Quarterly Technical Progress Report 2, January - March, 1987, AMAX Research \& Development Center, DOE Contract No. DE-AC21-86 M C23172, May 18, 1987. 
APPENDIX A

PHASE CONSTITUENTS IN ZINC FERRITE EXTRUDES 


\section{AMAX RESEARCH \& DEVELOPMENT CENTER INTEROFFICE MEMORANDUM}

Subject: Phase Constituents in Zinc Ferrite

Extrutes (80270)

July 27,1987

To: M. Berggren

From: J.R. Odekirk

Samples of roasted (indurated) zinc ferrite extrudes and iron oxide feedstock were analyzed by $\mathrm{X}$-ray diffraction to determine the phases present. Phases detected are as follows:

\begin{tabular}{lc} 
Iron oxide feedstocks & Phases \\
\hline $\begin{array}{l}\text { Pigment - Grade } \\
\text { Catalyst - Grade }\end{array}$ & $\begin{array}{l}\text { Hematite } \\
\text { Hernatite }\end{array}$ \\
Zinc ferrite extrudes & Phases \\
E-2 $\left(1500^{\circ} \mathrm{F}, 4 \mathrm{hrs}\right)$ & Franklinite $(90 \%)$, Hematite $(10 \%)$ \\
$\mathrm{E}-4\left(1900^{\circ} \mathrm{F}, 15 \mathrm{mins}\right)$ & Franklinite $(95 \%)$, Hematite $(5 \%)$ \\
$\mathrm{E}-7\left(1500^{\circ} \mathrm{F}, 4 \mathrm{hrs}\right)$ & Franklinite $(100 \%)$ \\
$\mathrm{E}-9\left(1900^{\circ} \mathrm{F}, 15 \mathrm{mins}\right)$ & Franklinite $(100 \%)$
\end{tabular}

The four zinc ferrite extrudes contained franklinite $\left(\mathrm{Zn} \mathrm{Fe}_{2} \mathrm{O}_{4}\right)$ except that samples E-2 and E-4 also contained unreacted hematite. Sample E-4 which was induratea at a higher temperature appears to contain less hematite.

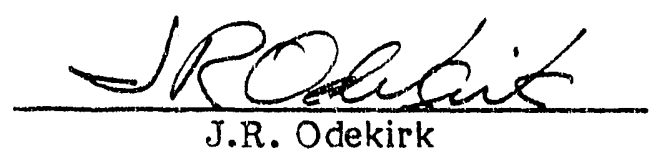

/lc

cc: A. Blandon

R.M. Rowe

MIN No. 87-8 


\section{APPENDIX B}

MINERALOGICAL ANALYSIS OF ZINC FERRITE SORBENT A-2-L-OX 


\section{AMAX RESEARCH \& DEVELOPMENT CENTER}

l. TEROFFICE MEMORANDUM

Subject: Mineralogical Analysis of Zinc Ferrite

September 24,1987

Sorbent A-2-L-OX (80270)

To: M. Jha

From: J.R. Odekirk

Introduction

A set of zinc ferrite extruded sorbent (UCI T-2465, cylindrical extrude) was investigated to determine the phases present and the distribution of iron, zinc and sulfur. The samples represent extrudes from the top and bottom portions of an oxidation-reduction reaction column where loading is accomplished from bottom to top. A specific sample of red colored extrudes from the top portion was analyzed in addition to the general top and bottom samples.

\section{Results}

$\mathrm{X}$-ray diffraction analysis was used to identify the various phase constituents. The phases detected are as follows:

\begin{tabular}{|c|c|c|c|}
\hline \multirow{2}{*}{ Sample } & \multicolumn{3}{|c|}{ Phases } \\
\hline & $\mathrm{ZnFe}_{2} \mathrm{O}_{4}$ & $\mathrm{Fe}_{2} \mathrm{O}_{3}$ & $\mathrm{ZnSO}_{4}$ \\
\hline A-2-L-OX Bottom & Major & - & - \\
\hline A-2-L-O X Top & Major & Minor & Minor \\
\hline A-2-L-OX Top (red) & Moderate & Moderate & Moderate \\
\hline
\end{tabular}

The variation in the amount of phases present suggests that the top portion of the column still contains extrudes which were only partially oxidize during regeneration.

Microscopic and electron microprobe analyses of the extrudes showed that both the top and bottom samples had a layered structure. The layering consisted of a fine-grained, competent $\mathrm{r} \mathrm{m}$ and a much softer, less competent core. Generally the rim is about one-fourth of the radius of the extrude. In the bottom sample, the rim and core consisted of $\mathrm{ZnFe}_{2} \mathrm{O}_{4}$, whereas, in the top sample only the rim consisted of $\mathrm{ZnFe}_{2} \mathrm{O}_{4}$, Figure 1. The core of the top sample contains what appears to be the $\mathrm{ZnSO}_{4}$ phase, Figure 2. 
$\mathrm{X}$-ray mapping by electron microprobe shows that the granular texture of $\mathrm{ZnFe}_{2} \mathrm{O}_{4}$ (franklinite) that formed in the core of the bottom extrudes, Figure 1, has not developed in the core of the top extrudes, Figure 2. Comparison of the texture and the distribution of $\mathrm{Zn}, \mathrm{Fe}$ and $\mathrm{S}$ in the core of the top and bottom samples suggests that the zine sulfate phase (zinkosite) could be somewhat fluid and as sulfur is expelled the fine-grain texture of franklinite is formed. Also, during the oxidation stage zinc tends to be mobil and forms a more homogeneous zinc and iron distribution. Mobilization of zinc after repeated sulfidation could result in its migration to the sorbent surface.

/1c

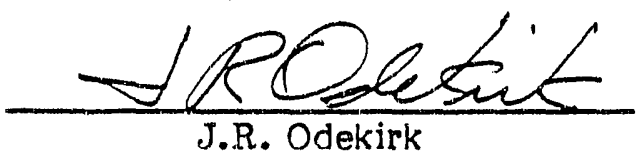

copy to: M. Rerggren

T.B. Cox

Min No.: $87-10$ and $87-22$ 

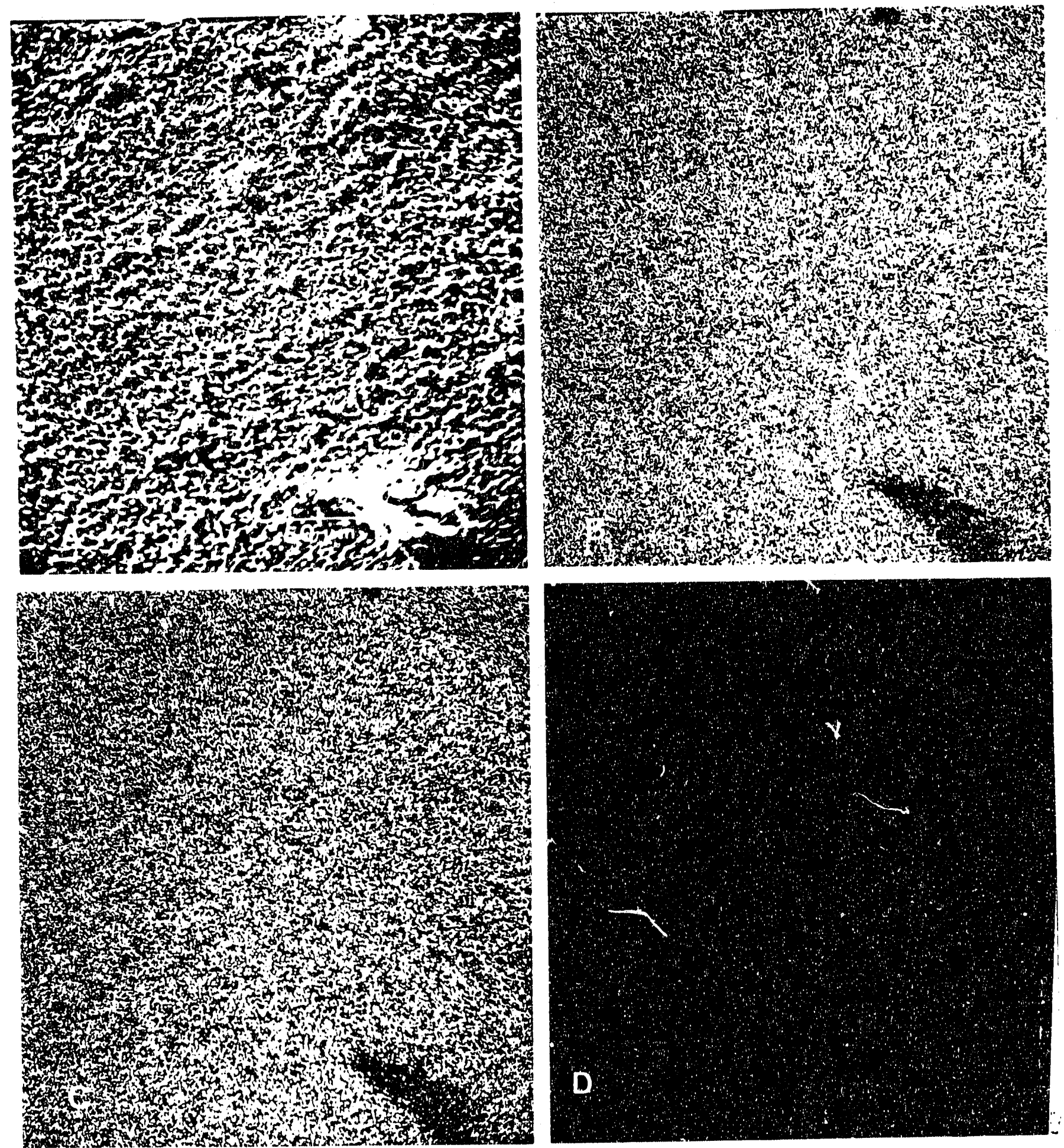

Figure 1. A-2-L-OX, Bottom-center.

A. Secondary electron image showing the fine-grained tecture of $\mathrm{ZnFe}_{2} \mathrm{O}_{4}$ (franklinite). $400 \mathrm{X}$

B. X-ray map showing iron distribution.

C. X-ray map showing zinc distribution.

D. X-ray map showing sulfur distribution. Spot densite is largely attributed to background rather than sulfur. 

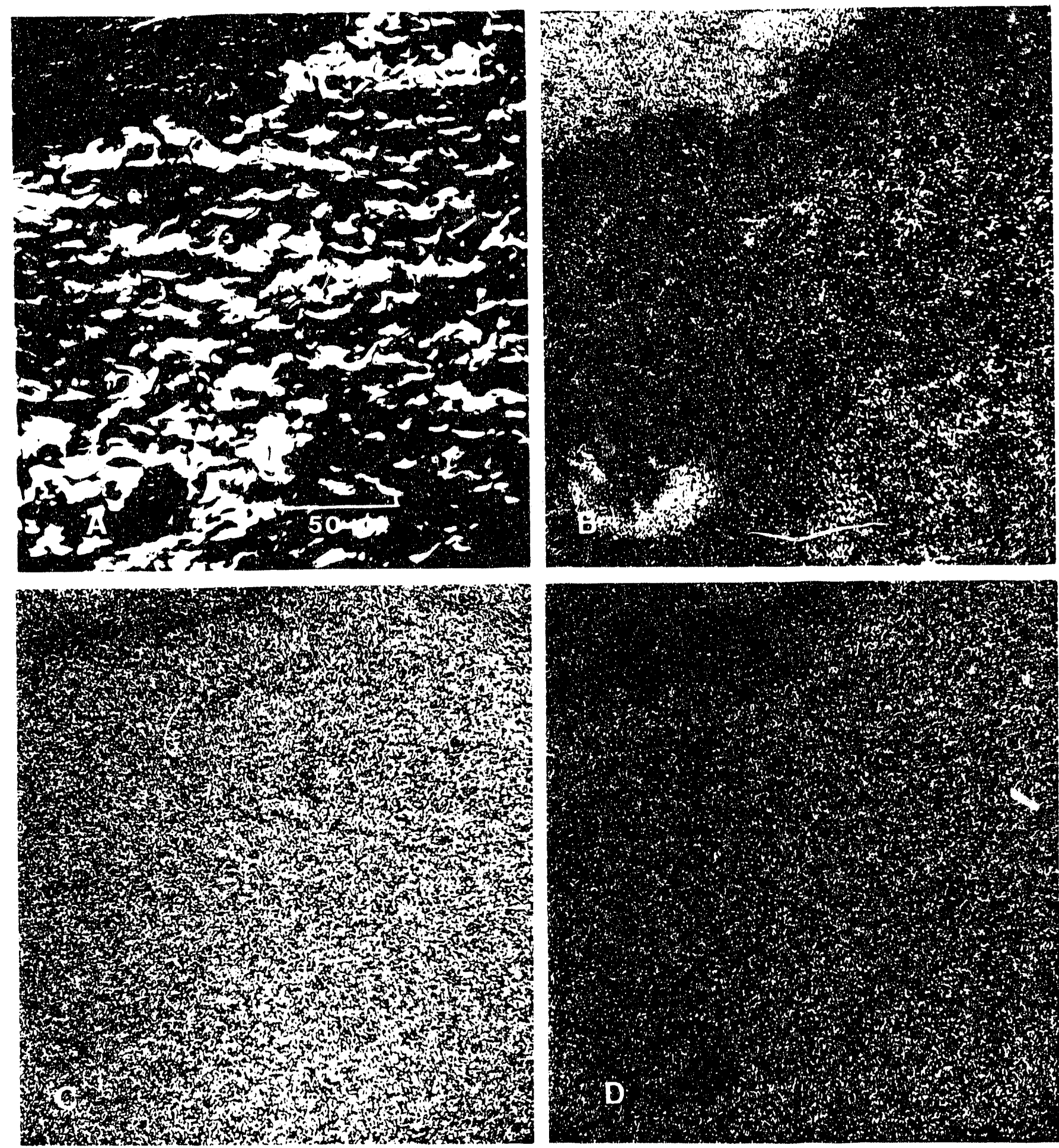

Figure 2. A-2-L-OX, Top-center.

A. Secondary electron image showing the texture of secondary zinc sulfate (zinkosite). $400 \mathrm{X}$

B. X-ray map showing iron distribution.

C. X-ray map showing zine distribution.

D. X-ray map showing sulfur distribution. Sulfur is closely associated with zinc. 

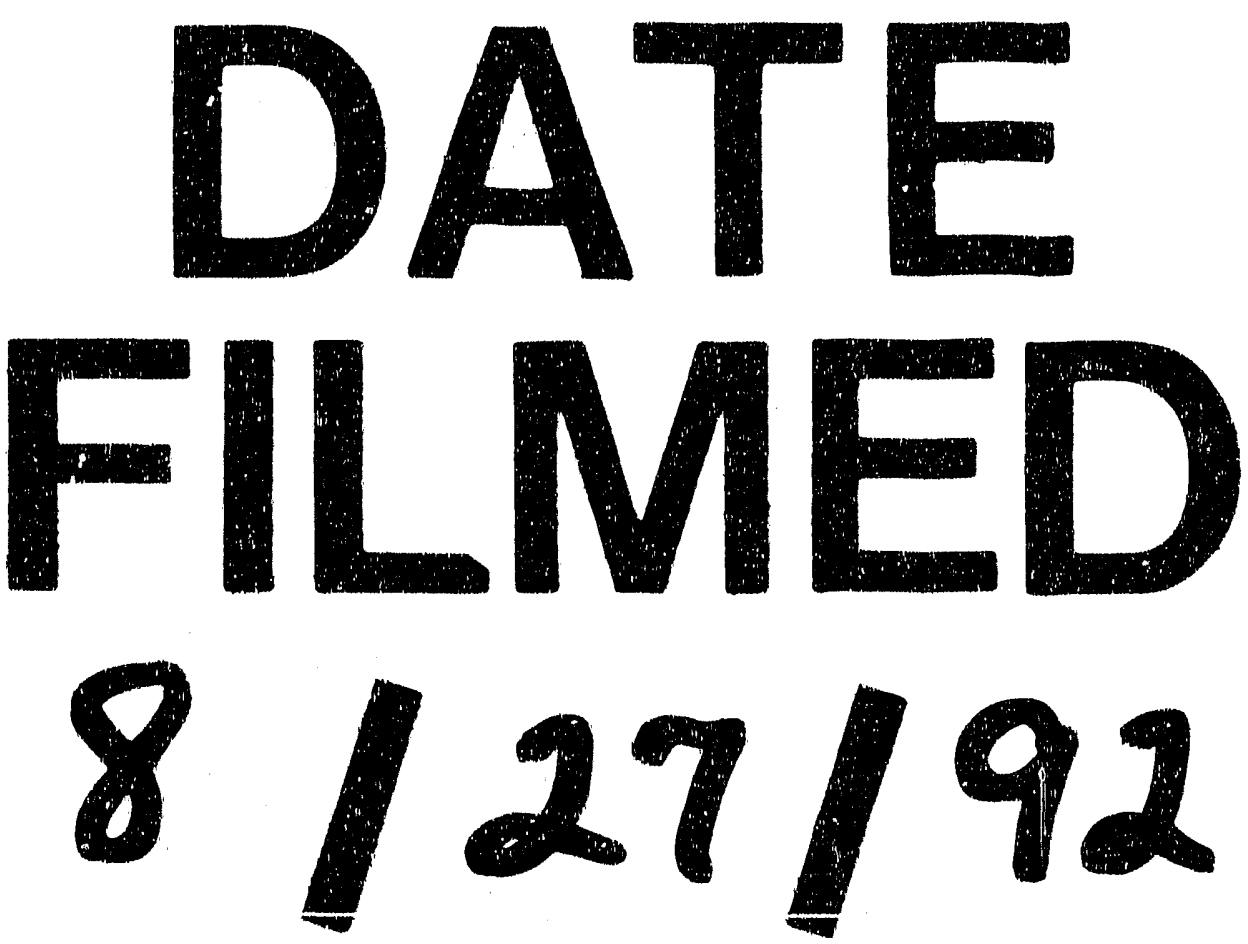
